\title{
Recruitment Aspects in the Agricultural Sector: Survey of Enterprises in the Czech Republic
}

\author{
Kateřina Drahotová1, Markéta Adamová2, Nikola Soukupová2, Andrea Jindrová1 \\ ${ }^{1}$ Faculty of Economics and Management, Czech University of Life Sciences Prague, Czech Republic \\ ${ }^{2}$ Faculty of Economics, University of South Bohemia in České Budějovice, Czech Republic
}

\begin{abstract}
Recruitment is one of the most important human resource management tools in the field of agriculture with reference to the current state of the labour market and the concept Agriculture 4.0. The first part of this article concentrates on the recruitment, on-line recruitment and recruitment methods. The second part evaluates the results of a quantitative survey carried out in the Czech Republic. The principal aim of this research project is to identify aspects in recruitment in the field of agriculture. Data were obtained by means of an electronic questionnaire completed by Czech agricultural enterprises $(\mathrm{N}=980)$. For data evaluation Chi-squared test was used. The survey shows that agricultural enterprises mostly prefer traditional methods for recruitment i.e. employee referral - 91.4\%; internal recruitment $-81.4 \%$. If on-line recruitment is used, then the website of the enterprise $(55.1 \%)$ is usually exploited. Moreover, the enterprises surveyed make less use of "mobile recruiting" - such as pracezarohem (11.4\%).
\end{abstract}

\section{Keywords}

Human resource management, labour market, agriculture, job analysis, recruitment, recruitment methods.

Drahotová, K., Adamová, M., Soukupová, N. and Jindrová, A. (2020) “Recruitment Aspects in the Agricultural Sector: Survey of Enterprises in the Czech Republic", AGRIS on-line Papers in Economics and Informatics, Vol. 12, No. 2, pp. 53-62. ISSN 1804-1930. DOI 10.7160/aol.2020.120205.

\section{Introduction}

The labour market in the Czech Republic is undergoing widespread transformation, in response to many challenges faced by Czech enterprises. In March 2019 the unemployment rate in the Czech Republic was $2.7 \%$ (actually $1.9 \%$ according to EUROSTAT methodology), this being the lowest for member states in the European Union (Figure 1). Consequently the average number of applicants per vacancy in this period was 0.6 (MPSV, 2019). Thus there is a significant problem finding qualified employees in general (Hedvicakova and Kral, 2018).

The agricultural sector represents a very small part of the national economy (ca. 2\%) and this, in part, is a disadvantage for the sector in its efforts to increase the number of well qualified employees (Trexima, 2018; Ministry of Agriculture, 2019). The proportion of agricultural employees in the total labour force in the Czech Republic has decreased progressively over the last 20 years. Whereas in 1993 almost $6 \%$ of employees worked in agriculture, in 2016 this had fallen to 3\%. In Romania, Bulgaria, and Greece there is employment rate in agriculture more than 10\% (EUROSTAT, 2017). In January 2015 , there were 16 skilled applicants per vacancy in the sector of agriculture, but in January 2018 there were only 2 applicants per vacancy. Within the traditional occupations, farms have difficulty in finding the right workforce not only for managerial positions (25\% of enterprises report problems), but also for auxiliary, unskilled employees (24\% of enterprises) (Czech Statistical Office, 2016; Trexima, 2018). This is also reflected, for example, in Sweden, where many agricultural positions are being filled by immigrants (Stenbacka, 2019).

One problem in the Czech agriculture labour market is that farm managers and owners are not sufficiently well qualified in agriculture. Another issue is that the average age of employees (45 years and over) is increasing - as illustrated in Figure 2 (Trexima, 2018; Czech Statistical Office, 2016). With comparison with the average age of agriculture workforce in European Union, it is the similar situation: $31.8 \%$ employees was below 40 years, $59.2 \%$ of those working in agriculture were $40-64$ years old and $9.0 \%$ were older than 


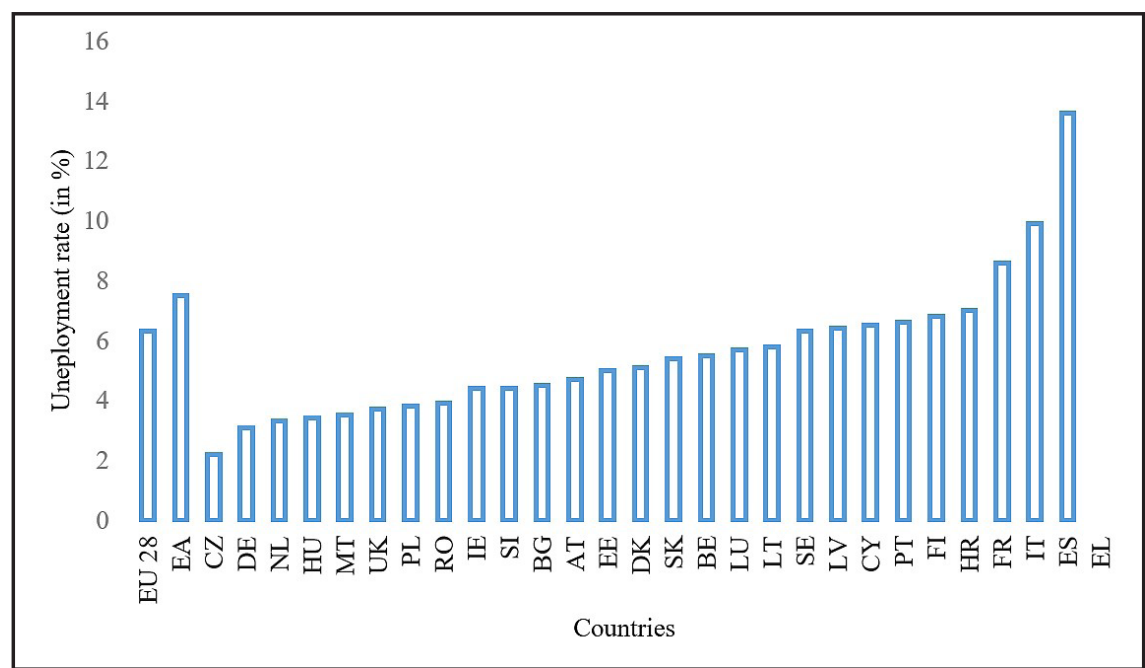

Note: EU - European Union, EA - European Area, CZ - Czech Republic, DE - Germany, NL Netherlands, HU - Hungary, PL - Poland, MT - Malta, RO - Romania, UK - United Kingdom, SI - Slovenia, EE - Estonia, BG - Bulgaria, AT - Austria, DK - Denmark, IE - Ireland, LU - Luxemburg, BE - Belgium, SK - Slovakia, LT - Lithuania, SE - Sweden, PT - Portugal, FI - Finland, CY - Cyprus, LV - Latvia, HR - Croatia, IT - Italy, ES - Spain, EL - Greece Source: EUROSTAT, 2019b

Figure 1: Unemployment rates in the EU (March 2019).

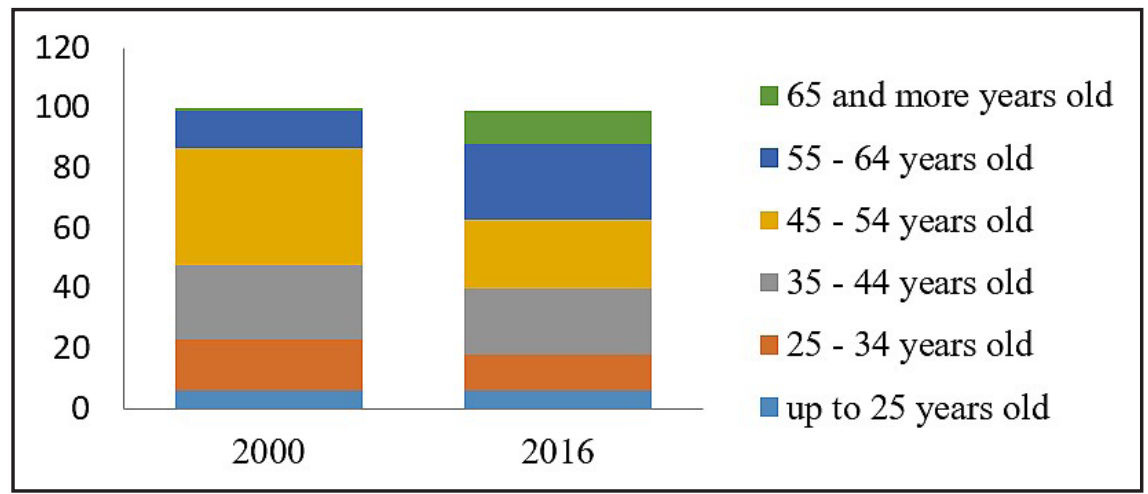

Source: according to Trexima, 2018

Figure 2: Changes in the age structure of the workforce in Czech agriculture (in \%).

64. A half of people working in agriculture reach medium level of education (EUROSTAT, 2017).

By 2020, employment in the agricultural sector is predicted to fall by around $10 \%$. In the next 10 years, formal job requirements are expected to increase in this sector in the Czech Republic than has been the case so far (Truhlikova et al., 2017). From these data, it can be concluded that an outflow of agricultural employees can be expected in the coming years and that employees, as they retire, will have to be replaced as a priority by a new generation. "The interest of young people working in agriculture is low because of high demand for unskilled labour, low wage levels in comparison with industry and the overall national economy of the Czech Republic" (Grigoryeva, 2012). Furthermore, it can be stated that the agriculture sector is not competitive within the labour market because the median monthly gross wage ranks in 13th position out of a total of 19 sectors. In addition, working in agriculture has a number of disadvantages: differing workloads during the year, variable weather effects, requirement for overtime, low job prestige, low wages, together with weekend shift-working. In the past two years, up to $85 \%$ of agricultural enterprises have faced labour shortages (Trexima, 2018), that have negative impact on the effectiveness of the agrarian sector as the whole. Human resources are crucial factor of the agrarian sector. Janecka et al. (2019) says that employees and cost on employees have impact on performance of farms. This lack of workforce could be solved the immigrants or the automation, robotics, and digitization, what represent massive 
investment of farmers. Zabmon et al. (2019) add that next step with agricultural sector "includes digitally-integrated enterprise, which rely their production processes using robotics and some forms of artificial intelligence Agriculture 4.0". Thus it is necessary to attract qualified candidates to agricultural sector by using effective and low cost recruitment methods.

The aim of this project is to identify aspects in recruitment in the agricultural sector. The partial aim is to identify recruitment methods used in Czech agricultural enterprises.

\section{Recruitment}

Recruitment is a process for attracting candidates to a vacancy, which involves the selection of candidates identified from external and internal sources (Brandão, Silva and dos Santos, 2019). The main goal is to hire motivated, engaged employees in appropriate quality and quantity (Laumer, Eckhardt and Weitzel, 2010; Stokes et al., 2017). The recruitment process consists of creating a pool of candidates, maintaining their interest and stimulating their choice (Kahlert, Botero and Prügl, 2017). Factors such as brand, corporate culture, the reward system, corporate prestige, job security and the variety of job functions play a role in decisions by candidates (Jones, Willness and Madey, 2014; Leekha Chhabra and Sharma, 2014; Kahlert, Botero and Prügl, 2017).

Traditional recruitment methods (Table 1) make sense from an employer's perspective rather than from an employee's point of view. In 2014, job portals were popular among students (Leekha, Chhabra and Sharma, 2014), but this is no longer the case. Technological advances have reshaped methods of recruiting (van Esch, Black and Ferolie, 2019). It is necessary to adapt recruitment to the Web 2.0 environment, including social networks (Ladkin and Buhalis, 2016). Recruiting employees through social networks is one of the methods that proves to be a suitable and effective tool. And this applies both to active recruitment of candidates, and to the passive, global recruitment of candidates, for example through LinkedIn - this was reported to be $61 \%$ in 2015 (El Ouirdi et al., 2016). Traditional recruitment has higher costs than online recruitment (Brandão, Silva and dos Santos, 2019). Ahmed (2012) concluded that cost issues play an important role in recruitment. According to Wenzelmann, Muehlemann and Pfeifer (2019) the costs of recruiting are twice the monthly salary for a vacant job position and ".. the costs of job postings increased by $53 \%$ " in recent years. The fees charged for job portals are high. Social media can reduce recruiting cost and save recruiting time (Hou and Li, 2017): in fact recruiting costs via social media have been shown to be nine times less than by traditional methods (Melanthiou et al., 2015).

\begin{tabular}{|c|c|}
\hline $\begin{array}{c}\text { Traditional methods } \\
\text { of recruiting }\end{array}$ & Online recruitment \\
\hline Referrals & Job portals \\
\hline Direct applicants & Enterprise (Career) webpages \\
\hline Advertisement in news & $\begin{array}{c}\text { Social media (Facebook, Twitter, } \\
\text { Google+, Instagram, Pinterest) }\end{array}$ \\
\hline Labour offices & $\begin{array}{c}\text { Professional networking sites } \\
\text { (LinkedIn, Facebook jobs, XING, } \\
\text { Research Gate) }\end{array}$ \\
\hline Head hunters & E-mail communication \\
\hline Personnel agencies & \\
\hline $\begin{array}{c}\text { Cooperation with } \\
\text { colleges and } \\
\text { universities }\end{array}$ & \\
\hline Enterprise databases & $\begin{array}{l}\text { Sources: Koch, Gerber and de Klerk, 2018; Bohmova } \\
\text { and Pavlicek, 2015; Gaupp-Berghausen et al., 2019; Holm } \\
\text { and Haar, 2019; Iannotta and Gatti, 2015 }\end{array}$
\end{tabular}

Table 1: Recruiting methods.

Online recruitment (otherwise known as internet recruitment or e-recruitment) means using advanced communication systems for attracting candidates (Brandão, Silva and dos Santos, 2019). Online recruitment enables pre-selection testing with concentration of all information in the one place. It is even possible to edit job adverts after posting. Candidates can be targetted in a better way than by traditional recruiting methods and this can cause a snowball effect. This helps create databases (which are permanent) with minimal sources required for collecting and managing data. E-recruitment can provide accurate information about candidates (because of possible screening within social networks), cut costs and increase efficiency. There is also a benefit for candidates in reducing their costs. Online recruitment has only a few disadvantages: first, there can be high numbers of applicants; next, there is the cost of implementation; and finally, there is a potential risk to the privacy of candidates (by screening the profile) (Brandão, Silva and dos Santos, 2019; Laumer, Eckhardt and Weitzel, 2010; Stokes et al., 2017; Hou and Xing, 2017).

According to Brandão, Silva and dos Santos (2019) the current trend in recruitment is moving towards online recruitment (Table 2). Breaugh (2013) add: "The way an organization recruits can influence the type of employees it hires." 


\begin{tabular}{|l|l|}
\hline $\begin{array}{l}\text { Enterprise/Career } \\
\text { webpages }\end{array}$ & $\begin{array}{l}\text { They are focused only on active } \\
\text { job seekers, who are interested } \\
\text { in the company. }\end{array}$ \\
\hline Job portals & They are really expensive. \\
\hline & $\begin{array}{l}\text { Social media used in recruiting } \\
\text { reduce recruiting costs and save } \\
\text { recruiting time. Recruiting costs } \\
\text { are nine times less than traditional } \\
\text { methods. Empirically Stokes et al. } \\
\text { (2017) found that they gained } \\
\text { more candidates through Facebook } \\
\text { than LinkedIn. Facebook itself has } \\
\text { around 5 200 000 unique users in } \\
\text { the Czech Republic. It has also been } \\
\text { proved that Facebook is an effective } \\
\text { LinkedIn, Pinterest, } \\
\text { Instagram, Xing) } \\
\text { tool for recruiting low earning } \\
\text { women through posting advertising } \\
\text { and surveys on Facebook. "The reason } \\
\text { why social media sites are suitable } \\
\text { for recruitment is the fact that there } \\
\text { is no limitation by salary, education } \\
\text { or geography on the internet." }\end{array}$ \\
\hline Mobile recruiting & $\begin{array}{l}\text { In 2016, a smart phone with internet } \\
\text { access was used by 58\% of Czech } \\
\text { citizens; 42\% are online via mobile } \\
\text { as frequently as they use a computer. }\end{array}$ \\
\hline
\end{tabular}

Source: Bohmova and Pavlicek, 2015; Hou and Li, 2017; Melanthiou et al., 2015; Stokes et al., 2017; Lorenc, 2018; Hou and Li, 2017; Google, 2017

Table 2: Trends in recruitment.

\section{Materials and methods}

A quantitative survey was conducted in the Czech Republic from December 2018 to January 2019 to identify aspects in recruitment as used in the field of agriculture and to evaluate attitudes towards them. A subsidiary aim was to identify recruitment methods currently used by agricultural enterprises in the Czech labour market. The quantitative survey was carried out on the basis of a questionnaire comprising of 15 questions, five of which were qualitative in nature. 9 questions were based on multiple choice.

The sample group consisted of 980 agricultural enterprises. The questionnaire return rate was $12.04 \%$ (118), of which micro-enterprises (up to 9 employees) accounted for $15.3 \%$, small enterprises (from 10 employees to 49 employees) for $53.4 \%$, and medium-sized enterprises (from 50 to 249 employees) accounted for $31.4 \%$ of the sample. It is not possible to determine the exact number of agricultural organizations with more than 250 employees, as the size of large agricultural organizations is usually measured according to the area of agricultural land rather than the number of employees. The classification of enterprise size was according to the European Commission Recommendation (No. 2003/361/ES).
In terms of their areas of production, the most frequent types were mixed production $(83.1 \%)$, followed by animal husbandry (9.3\%), while $7.6 \%$ enterprises were focused on plant production.

The data obtained were processed by means of absolute and relative frequencies. Based on two qualitative variables the data were sorted into a contingency table. Testing was carried out using the Pearson Chi-Square test in contingency tables. To interpret the strength of relationship coefficients (Cramer's coefficient), a scale according to Rezankova (2011) was used. If the conditions of the Pearson Chi-Square test were not complied with, Fisher's Exact Test was used. For testing statistical hypotheses and for subsequent analysis, a level of significance $\alpha=0.05$ was used. The conditions for testing by means of the Pearson Chi-Square test in contingency tables are that no more than $80 \%$ of cells have an expected count of less than 5, and other cells have an expected count value less than 1. The practical calculations were made using MS Excel and the statistical software SPSS (version 24).

\section{Results and discussion}

\section{A) Recruitment methods applied in agricultural enterprises in the Czech Republic}

This survey has shown that agricultural enterprises use traditional methods of recruitment, rather than on-line recruitment. Among the reasons for not utilising on-line recruitment more extensively, one factor may be that in agricultural enterprises it is usually the CEOs who set the job requirements (depending on the position in the company: from $37.3 \%$ till $89 \%$ ) rather than HR representatives (depending on the position in the company: from $0.8 \%$ till $5.9 \%$ ) in cooperation with senior managers (depending on the position in the company: from $11.9 \%$ till $75.4 \%$ ).

It is mainly the managers directly involved who know what type of employees are needed for a particular vacancy (LMC, 2019). An HR specialist might only have an advisory role and serve as manager of the process. Another reason for not using online recruitment more often could be that agricultural enterprises do not carry out job analysis (59.3\%) prior to starting the recruitment process. If they do, then it is mostly for management positions $(62.5 \%)$ and specialists (47.9\%). Job design and job analysis represent the basic pillars of other personnel activities and these are the key elements of the recruitment 
process. Moreover, it is mostly small-sized enterprises $(50 \%)$ and medium-sized enterprises $(35.4 \%)$ that conduct job analysis (Table 3 ).

However, agricultural enterprises usually carry out job analysis when they create a new job position (91.7\%) and when any change of a job position occurs $(85.4 \%)$. It is the most effective way to recruit high quality future employees, who fit the current requirements for a vacancy. The senior managers directly involved with a post usually conduct job analysis (97.9\%), and are the best qualified to do this.

In this survey $81.4 \%$ of agricultural enterprises stated that for recruitment they mostly use the following: employee referral $(94.1 \%)$, direct applications (86.4\%), internal sourcing (81.4\%) and cooperation with a local Labour Office $(80.4 \%)$. In the Czech Republic $75 \%$ of enterprises post their vacancies on enterprise websites; and more than half have a profile on Facebook and LinkedIn (Eger at al., 2017). According to a survey in Slovakia companies prefer internal recruiting (Delgadova, Gullerova and Ivanova, 2017). Stenbacka (2019) reports that employee referrals function well in Sweden-occasionally they use personnel agencies and other external services for recruitment (16.1\%). The use of personnel agencies does not depend on the enterprise size or the area of production (Table 4). Swedish farmers see personnel agencies as being problematic (Stenbacka, 2019). On the other hand Iannotta and Gatti (2015) conclude that: "Traditional recruiting systems have been gradually replaced by online recruitment." Koch et al. (2018) agree: "Traditional job advertising is moving to electronic advertising." Brandão et al. (2019) add that in Portugal on-line recruitment is very much underutilized method. Traditional methods is considered ineffective and expensive, so it is necessary to focus on online recruitment.

In addition, they rarely work with a database of potential candidates $(22 \%)$. The database is permanent and it is possible to contact candidates immediately, but the quality of the database is important. Also, agricultural enterprises contact potential candidates directly $(31.4 \%)$. Choosing to directly contact potential candidates does not depend on the size of the enterprise or the area of production (Table 5).

B) Aspects in employee sourcing used by agricultural enterprises in the Czech Republic

Agricultural enterprises advertise mainly on their own enterprise web-pages $(55.1 \%)$. The results confirmed that advertisements on their own web-

\begin{tabular}{|c|c|c|c|c|}
\hline \multirow{2}{*}{ Job analysis } & \multicolumn{3}{c|}{ Enterprise size } \\
\cline { 3 - 5 } & Micro-sized enterprises & Small-sized enterprises & $\begin{array}{c}\text { Medium and large- } \\
\text { scale enterprises }\end{array}$ \\
\hline Yes & Relative Frequency & $14.6 \%$ & $50 \%$ & $35.4 \%$ \\
\hline No & Relative Frequency & $15.7 \%$ & $55.7 \%$ & $28.6 \%$ \\
\hline
\end{tabular}

Source: Authors' survey, 2019

Table 3: Carrying out job analysis according to enterprise size.

\begin{tabular}{|c|l|c|c|}
\hline Number of hypothesis & Null hypothesis $\left(\mathbf{H}_{\mathbf{0}}\right)$ & P-value & Rejection of $\mathbf{H}_{\mathbf{0}}$ \\
\hline 1 & $\begin{array}{l}\text { The use of external sources - personnel agencies } \\
\text { does not depend on the size of an enterprise }\end{array}$ & 0.410 & No \\
\hline 2 & $\begin{array}{l}\text { The use of external sources - personnel agencies } \\
\text { does not depend on the production field }\end{array}$ & 0.471 & No \\
\hline
\end{tabular}

Source: Authors' survey, 2019

Table 4: The results of the qualitative characteristics test for hypotheses 1 and 2 .

\begin{tabular}{|c|l|c|c|}
\hline Number of hypothesis & Null hypothesis $\left(\mathbf{H}_{\mathbf{0}}\right)$ & P-value & Rejection of $\mathbf{H}_{\mathbf{0}}$ \\
\hline 3 & $\begin{array}{l}\text { The use of external sources - directly contacting } \\
\text { potential candidates does not depend on the size } \\
\text { of an enterprise }\end{array}$ & 0.283 & No \\
\hline 4 & $\begin{array}{l}\text { The use of external sources - directly contacting } \\
\text { potential candidates does not depend on the area } \\
\text { of production field }\end{array}$ & 0.099 & No \\
\hline
\end{tabular}

Source: Authors' survey, 2019

Table 5: The results of the qualitative characteristics test for hypotheses 3 and 4 . 
pages are mostly used by small and mediumsized agricultural enterprises (Table 6). These webpages are considered to be "a vital source of information for job candidates" - as confirmed by Banks et al. (2019), whose research showed that $98.2 \%$ of respondents used employer websites for their job searches. Priyadarshini et al. (2019) add that ,providing relevant, accurate, and timely information on the corporate website will serve as a central cue for the job seekers to self-select or opt-out themselves from the recruitment process". However, they seldom use mobile recruiting - and agricultural enterprises make little use of websites for smart mobile phones, such as pracezarohem (11.4\%). Nevertheless, in the Czech Republic one million people have downloaded the pracezarohem application (LMC, 2019).

Currently, agricultural enterprises seldom use job portals $(37.3 \%)$. If they use job portals for advertising for recruits, then they use the two largest Czech job portals - jobs.cz (79.5 \%) and prace.cz (65.9\%). After these the other job portals used are: dopraprace.cz (18.2\%) and profesia.cz $(2.3 \%)$. The present results show that job portals are becoming more popular for recruitment in agriculture.

Agricultural enterprises do not use social media for sourcing employees if they use mainly small sized enterprises (87.3\%). According to EUROSTAT (2019b) the use of social networking in enterprises is increasing. Within the EU, only $9 \%$ of enterprises used social networks to recruit in 2013 - this increased to $23 \%$ in 2017.

The smaller enterprises mainly use social media for employee sourcing, as do micro-sized enterprises
(Table 7). According to EUROSTAT (2019b) $72 \%$ of large enterprises used social networks to recruit, while only $45 \%$ of small enterprises used social networks as a tool for recruitment.

According to European survey considering the invested working hours, Facebook as a social medium was also one of the most time-efficient recruitment methods (Gaupp-Berghausen et al., 2019). The advantages of social media are aiming not only to active candidates but even to passive candidates. And using social medias could have positive impact on employer brand, improvement of image agricultural sector and increasing of young people interest in agriculture sector.

\section{Conclusion}

Currently, many managers and owners in the field of agriculture in the Czech Republic are not sufficiently well qualified. Also, the average age of employees (45 years and over) is increasing. So employees as they retire must be replaced by a new generation. The choice of recruitment method to meet this challenge is crucial for future success as well as for maintaining competitive advantage. This survey shows that agricultural enterprises mostly prefer traditional methods for recruitment, namely: employee referral - 91.4\%; internal recruitment - 81.4\%; direct application - 86.4\%; Labour Office - 80.5\%. Personnel agencies and other external services are seldom used for recruitment $(16.1 \%)$. The use of personnel agencies does not appear to depend on the size of an enterprise $(p=0.410)$, nor on the area of production $(\mathrm{p}=0.471)$. Moreover, databases of potential candidates are not often used for recruitment (22\%). If on-line recruitment

\begin{tabular}{|c|c|c|c|c|}
\hline \multirow{2}{*}{\multicolumn{2}{|c|}{$\begin{array}{c}\text { Job advertisement } \\
\text { on enterprise web-pages }\end{array}$}} & \multicolumn{3}{|c|}{ Enterprise size } \\
\hline & & \multirow{2}{*}{$\frac{\text { Micro-sized enterprises }}{7.7 \%}$} & \multirow{2}{*}{$\begin{array}{c}\text { Small-sized enterprises } \\
53.8 \%\end{array}$} & \multirow{2}{*}{$\begin{array}{c}\begin{array}{c}\text { Medium and large- } \\
\text { scale enterprises }\end{array} \\
38.5 \%\end{array}$} \\
\hline Yes & Relative Frequency & & & \\
\hline No & Relative Frequency & $24.5 \%$ & $52.8 \%$ & $22.6 \%$ \\
\hline
\end{tabular}

Source: Authors' survey, 2019

Table 6: The use of job advertisements on enterprise web-pages in relation to enterprise size.

\begin{tabular}{|c|c|c|c|c|}
\hline \multirow{2}{*}{ Social media } & \multicolumn{3}{c|}{ Enterprise size } \\
\cline { 3 - 5 } & Micro-sized enterprises & Small-sized enterprises & $\begin{array}{c}\text { Medium and large- } \\
\text { scale enterprises }\end{array}$ \\
\hline Yes & Relative Frequency & $13.3 \%$ & $60 \%$ & $26.7 \%$ \\
\hline No & Relative Frequency & $15.5 \%$ & $52.5 \%$ & $32 \%$ \\
\hline
\end{tabular}

Source: Authors' survey, 2019

Table 7: Use of social media for recruitment according to enterprise size. 
is used, then enterprise websites $(55.1 \%)$ are utilised, mostly by small (53.8\%) and mediumsized $(38.5 \%)$ agricultural enterprises. On the other hand, agricultural enterprises tend not to use mobile recruiting based on smart mobile phones - via the websites pracezarohem $(11.4 \%)$, social media $(12.7 \%)$ and job portals $(37.3 \%)$.

Among the reasons for on-line recruitment not being used, one factor may be that it is usually CEOs of agricultural enterprises who set job requirements, rather than $\mathrm{HR}$ representatives in cooperation with senior managers. Another factor may be that agricultural enterprises do not carry out job analysis (59.3\%) prior to recruitment. If they do, then this is only for certain positions, often during creation of a new post $(91.7 \%)$, or when there is a change in a job position (85.4\%). Small-sized agricultural enterprises use social media as an effective recruitment method. This method is inexpensive, saves time and attracts more candidates who are suitable. Social media might be used for really specialized posts and also for posts requiring low qualifications, when there are no geographical limitations (Bohmova and Pavlicek, 2015; Hou and Li, 2017; Melanthiou et al., 2015; Stokes et al., 2017; Lorenc, 2018; Hou and Li, 2017; Google, 2017). Job portals are becoming more popular for recruitment in agriculture than in the past. So it is proposed that agricultural enterprises should focus on using online recruitment, to attract the best candidates, face the lack of workforce and thereby gain competitive advantage. Recruitment has its economic aspect - it means cost. E.g. in USA companies spend on hiring an average of $\$ 4,129$ per fill one vacancy (Cappelli, 2019). Average the costs of recruiting are twice the monthly salary for a vacant job position and it is expected their increasing by $53 \%$ in recent years in Europe. Online recruitment methods are more effective, they enable companies to attract more candidates and they are effective in reducing the cost, time, and efforts. Using social networks is cheapest, recruiting costs are nine times less than traditional methods (Brandão, Silva and dos Santos, 2019; Wenzelmann, Muehlemann and Pfeifer, 2019). Besides the agricultural sector face the challenge of Agriculture 4.0 and it will need enough qualified employees.

\section{Acknowledgments}

The paper was supported by the Faculty of Economics, the University of South Bohemia in Ceske Budejovice within the project IGS28C1: „Vzajemne vazby $\mathrm{v}$ systemu BSC v ramci rizeni podniku“".

\section{Corresponding authors}

Ing. Katerina Drahotová, Ph.D.

Department of Management, Faculty of Economics and Management,

Czech University of Life Sciences Prague, Kamýcká 129, 16500 Praha - Suchdol, Czech Republic

E-mail:drahotovak@pef.czu.cz

\section{References}

[1] Ahmed, A. F. (2009) "The Employability of Graduates in Competitive Organizations", Business Intelligence Journal, Vol. 2, No. 2, pp. 288-318. ISSN 1918-2325.

[2] Banks, G. C., Woznyj, H. M., Wesslen, R. S., Frear, K. A., Berka, G., Heggestad, E. D. and Gordon, H. L. (2019) "Strategic Recruitment Across Borders: An Investigation of Multinational Enterprises“, Journal of Management, Vol. 45, No. 2, pp. 476-509. ISSN 0149-2063. DOI 10.1177/0149206318764295.

[3] Bohmova, L. and Pavlicek, A. (2015) "The influence of social networking sites on recruiting human resources in the Czech Republic", Organizacija, Vol. 48, No. 1, pp. 23-31. ISSN 13185454. DOI 10.1515/orga-2015-0002.

[4] Brandão, C., Silva, R. and dos Santos, J. V. (2019) "Online recruitment in Portugal: Theories and candidate profiles", Journal of Business Research, Vol. 94, pp. 273-279. ISSN 0148-2963. ISSN 0148-2963. DOI 10.1016/j.jbusres.2018.04.011.

[5] Breaugh, J. A. (2013) "Employee Recruitment“, Annual Review of Psychology, Vol. 64, No. 1, pp. 389-416. ISSN 0066-4308. DOI 10.1146/annurev-psych-113011-143757.

[6] Cappelli P. (2019) “Your Approach to Hiring Is All Wrong”, Harvard Business Review. [Online], Available: https://hbr.org/2019/05/recruiting [Accessed: 22 January 2020]. 
[7] Commission Recommendation (No. 2003/361/ES) (2003) "Commission Recommendation of 6 May 2003 concerning the definition of micro, small and medium-sized enterprises", EU. [Online]. Available: https://eur-lex.europa.eu/LexUriServ/LexUriServ.do?uri=OJ:L:2003: 124:0036:0041:EN:PDF Available: [Accessed: 10 June 2019].

[8] Czech Statistical Office (2016) “Strukturální šetření v zemědělství - 2016”, Czech Republic, [Online], Available: https:/www.czso.cz/csu/czso/zemedelstvi-celkem [Accessed: 1 April 2019]. (In Czech).

[9] Delgadova, E., Gullerova, M. and Ivanova, E. (2017) "Recruitment and selection processes in Slovak enterprises and multinational corporations", International Journal of Organizational Leadership, Vol. 6, No. 2, pp. 211-220. ISSN 2345-6744. DOI 10.33844/ijol.2017.60241.

[10] Eger, L., Egerova, D., Micik, M. and Prantl, D. (2017) "Corporate and recruitment websites as tools for recruiting”, In Proceedings of the International Scientific Conference of Business Economics, Management and Marketing (Iscobemm 2017), pp. 65-75. ISBN 978-80-210-8714-9.

[11] El Ouirdi, M., Pais, I., Segers, J. and El Ouirdi, A. (2016) "The relationship between recruiter characteristics and applicant assessment on social media", Computers in Human Behavior, Vol. 62, pp. 415-422. ISSN 07475632. DOI 10.1016/j.chb.2016.04.012.

[12] EUROSTAT (2017) "Farmers in the EU - statistics“, EU. [Online]. Available: https://ec.europa.eu/ eurostat/statisticsexplained/index.php/Farmers_in_the_EU_-_statistics [Accessed: 8 October 2019].

[13] EUROSTAT (2019a) "Employment and unemployment: Labor force survey", EU. [Online]. Available: http://ec.europa.eu/eurostat/web/lfs/data/database [Accessed: 10 April 2019].

[14] EUROSTAT (2019b) "Social media - statistics on the use by enterprises", Statistics Explained, EU [Online]. Available at: https://ec.europa.eu/eurostat/statistics-explained/index.php/Social_media statistics_on_the_use_by_enterprises\#Use_of_social_media_by_enterprises [Accessed: 10 April 2019].

[15] Gaupp-Berghausen, M., Raser, E., Anaya-Boig, E., Avila-Palencia, I., de Nazelle, A., Dons, E., ... and Hössinger, R. (2019) "Evaluation of Different Recruitment Methods: Longitudinal, Web-Based, Pan-European Physical Activity Through Sustainable Transport Approaches (PASTA) Project", Journal of Medical Internet Research, Vol. 21, No. 5. ISSN 1438-8871. DOI 10.2196/11492.

[16] Google (2017) "Počet Čechů pripojených $k$ internetu ze třech a více zařizení se od roku 2012 zdesetinásobil" (The number of Czechs on the Internet has increased tenfold since 2012), Czech Republic, [Online]. Available: https://googlepresscz.blogspot.com/2017/02/ studiegooglupocetcechupripojenychk.html\#735b9/ [Accessed: 10 April 2019] (In Czech).

[17] Grigoryeva, N. (2012) "The problem of youth unemployment in rural area“, Agris On-line Papers in Economics and Informatics, Vol. 4, No. 1, pp. 3-12. ISSN 18041930.

[18] Hedvicakova, M. and Kral, M. (2018) "Level of Industry automation 4.0 in the Czech Republic and impact on unemployment", In European Financial Systems 2018 Proceedings of the 15th International Scientific Conference, pp. 160-167. ISBN 978-80-210-8980-8.

[19] Holm, A. B. and Haahr, L. (2019) "e-HRM: Digital Approaches, Directions \& Applications", New York: Routledge. ISBN 978-1-138-04394-7.

[20] Hou, B. and Li, X. (2017) "Study on Social Media is an Effective Platform to Use When Recruiting“, In Advances in Computer Science Research (ACSR): 7th International Conference on Education, Management, Information and Mechanical Engineering (EMIM 2017), Vol. 76, pp. 1793-1796. ISSN 2352-538X. DOI 10.2991/emim-17.2017.365.

[21] Iannotta, M. and Gatti, M. (2015) "Innovating e-Recruitment Services: An Italian Case Study”, Empowering Organizations, Vol. 11, No. 1, pp. 103-114. ISSN 21954968. DOI 10.1007/978-3-319-23784-8_9.

[22] Janecka, M., Homolka, J., Hoskova, P., Mach, J. and Dvorak, M. (2019) "Evaluation of Economic Efficiency of Selected Branch in Animal Production in EU and CR", AGRIS on-line Papers in Economics and Informatics, Vol. 11, No. 4, pp. 15-30. ISSN 1804-1930. DOI 10.7160/aol.2019.110402. 
[23] Jones, D. A., Willness, C. R. and Madey, S. (2014) "Why Are Job Seekers Attracted by Corporate Social Performance? Experimental and Field Tests of Three Signal-Based Mechanisms“, Academy of Management Journal, Vol. 57, No. 2, pp. 383-404. E-ISSN 1948-0989, ISSN 0001-4273. DOI 10.5465/amj.2011.0848.

[24] Kahlert, C., Botero, I. C. and Prügl, R. (2017) "Revealing the family effects of being perceived as a family firm in the recruiting market in Germany", Journal of Family Business Management, Vol. 7, No. 1, pp. 21-43. ISSN 2043-6238. DOI 10.1108/jfbm-10-2015-0037.

[25] Koch, T., Gerber, C. and de Klerk, J. J. (2018) "The impact of social media on recruitment: Are you LinkedIn?", SA Journal of Human Resource Management, Vol. 16, No. 1, pp. 1-14, ISSN 1683-7584. DOI 10.4102/sajhrm.v16i0.861.

[26] Ladkin, A. and Buhalis, D. (2016) "Online and social media recruitment: Hospitality employer and prospective employee considerations“, International Journal of Contemporary Hospitality Management, Vol. 28, No. 2, pp. 327-345. ISSN 17571049. DOI 10.1108/IJCHM-05-2014-0218.

[27] Laumer, S., Eckhardt, A. and Weitzel, T. (2010) "Electronic human resources management in an e-business environment", Journal of Electronic Commerce Research, Vol. 11, No. 4, pp. 240-250. ISSN 1526-6133.

[28] Leekha Chhabra, N. and Sharma, S. (2014) "Employer branding: strategy for improving employer attractiveness", International Journal of Organizational Analysis, Vol. 22, No. 1, pp. 48-60. ISSN 1934-8835. DOI 10.1108/IJOA-09-2011-0513.

[29] LMC (2019) "Připad Letiště: Zapojte šéfy budoucích zaměstnanců do náboru. Vyplatí se to všem" (Airport Case: Engage future bosses. It pays off to everyone), Czech Republic. [Online]. Available: https://www.lmc.eu/cs/magazin/clanky/pripad-letiste-zapojte-sefy-budoucich-zamestnancu-donaboru-vyplati-se-to-vsem/ [Accessed: 10 June 2019]. (In Czech).

[30] Lorenc. J. (2018) "Social Media stats and demographics in the Czech Republic". LinkedIn. [Online]. Available: https://www.linkedin.com/pulse/social-media-stats-demographics-czech-republic-jakublorenc/ [Accessed: 1 April 2019].

[31] Melanthiou, Y., Pavlou, F. and Constantinou, E. (2015) "The use of social network sites as an e-recruitment tool", Journal of Transnational Management, Vol. 20, No. 1, pp. 31-49. E-ISSN 1547-5786, ISSN 1547-5778. DOI 10.1080/15475778.2015.998141.

[32] Ministry of Agriculture (2019) "Ministerstvo zemědělství، (Ministry of Agriculture), Czech Republic, [Online], Available: http://eagri.cz/public/web/mze/ministerstvo-zemedelstvi/proexportni-okenko/ zahranicni-pracovnici/ [Accessed: 1 April 2019]. (In Czech).

[33] MPSV (2019) "Nezaměstnanost v dubnu opět klesla“ (Unemployment decreased again in April), [Online]. Available:https://portal.mpsv.cz/upcr/media/tz/2019/05/2019_05_10_tz_nezamestnanost duben_2019.pdf [Accessed: 24 May 2019]. (In Czech).

[34] Priyadarshini, C., Sreejesh S. and Jha, R. R. (2019) "Impact of Informational Characteristics of the Recruitment Website on Graduating Students' Job Pursuit Intention“, International Journal of Human Capital and Information Technology Professionals, Vol. 10, No. 2, pp. 1-19. E-ISSN 1947-3486, ISSN 1947-3478. DOI 10.4018/ijhcitp.2019040101.

[35] Rezankova, H. (2011) "Analýza dat z dotaznikových šetřeni" (Analysis of questionnaire data). Professional Publishing. ISBN 9788074310621. (In Czech).

[36] Stenbacka, S. (2019) "Responsibilities, caring practices and agriculture: Farmers' perspectives on recruitment and employer - employee relationships“, Sociologia Ruralis, Vol. 59, No. 2, pp. 255-274. ISSN 00380199. DOI 10.1111/soru.12223.

[37] Stokes, Y., Vandyk, A., Squires, J., Jacob, J.-D. and Gifford, W. (2017) "Using Facebook and LinkedIn to Recruit Nurses for an Online Survey", Western Journal of Nursing Research, Vol. 41, No. 1, pp. 96-110. ISSN 0193-9459. DOI 10.1177/0193945917740706. 
[38] Trexima (2018) “Vliv digitalizace a robotizace na charakter práce a roli sociálního dialogu $v$ zemédélstvi" (The impact of digitization and robotization on the nature of work and the role of social dialogue in agriculture), Czech Republic. [Online], Available: https:/www.zscr.cz/media/ upload/1527066127_agrodialog-ii-studie-final-20180430.pdf [Accessed: 1 April 2019]. (In Czech).

[39] Truhlikova, J. (2017) “Absolventi středních škol a trh práce?: Odvětví zemédělstvi”" (High school graduates and the labor market?: Agriculture sector), Národní ústav pro vzdělávání, školské poradenské zařízení a zařízení pro další vzdělávání pedagogických pracovníků. [Online]. Available: https:/www.infoabsolvent.cz/Temata/PublikaceAbsolventi?Stranka=9-0-120\&Stranka=9-0-120 [Accessed: 1 April 2019]. (In Czech).

[40] van Esch, P., Black, J. S. and Ferolie, J. (2019) "Marketing AI recruitment: The next phase in job application and selection", Computers in Human Behavior, Vol. 90, pp. 215-222. ISSN 0747-5632. DOI 10.1016/j.chb.2018.09.009.

[41] Wenzelmann, F., Muehlemann, S. and Pfeifer, H. (2017) "The costs of recruiting apprentices: Evidence from German workplace-level data", German Journal of Human Resource Management, Vol. 31, No. 2, pp. 108-131. ISSN 2397-0022. DOI 10.1177/2397002216683863.

[42] Zambon, I., Cecchini, M., Egidi, G., Saporito, M. G. and Colantoni, A. (2019) "Revolution 4.0: Industry vs. Agriculture in a Future Development for SMEs“, Processes, Vol. 7, No. 1, pp. 36. ISSN 2227-9717. DOI 10.3390/pr7010036. 